\section{FORMATION OF 3/2 ELECTRON COMPOUNDS IN ALLOYS OF COPPER, SILVER, AND GOLD}

TN many alloys of copper, silver, and gold with the elements of the $B$-sub-groups, the phase next to the $\alpha$ solid solution has a composition near that required by an electron concentration of $1 \cdot 5$, and for convenience these may be called the $3 / 2$ electron compounds. The crystal structures of these are of three types: (1) body-centred cubic structures, either disordered $(\beta)$ or ordered $\left(\beta^{\prime}\right) ;(2)$ close-packed hexagonal types $\left(\zeta\right.$ or $\left.\zeta^{\prime}\right)$; (3) $\beta$-manganese type (denoted $\mu$ ).

A review of the existing data by $W$. HumeRothery, P. W. Reynolds and G. V. Raynor ( $\mathcal{~}$. Inst. Metals, 66, 1940), shows that the $3 / 2$ electron compounds are formed only when the size-factors are reasonably favourable, the term 'size-factor' being used to denote the difference between the atomic diameters of solvent and solute. A detailed examination leads to the following generalizations : $(a)$ increasing valency favours the $\zeta$ or $\mu$ structures at the expense of the $\beta$ or $\beta^{\prime}$ structures; $(b)$ increasing temperature favours the $\beta$ structures at the expense of the $\beta^{\prime}, \zeta$, or $\mu$ structures; $(c)$ increasing size-factor favours the $\beta$ structures at the expense of the $\zeta$ or $\mu$ structures; $(d)$ increasing the size-factor moves the composition of the $3 / 2$ electron compounds in the direction of lower electron concentration, and also narrows the range of composition of the phases in terms of electron concentration ; $(e)$ the tendency to form ordered $\beta^{\prime}$ structures in copper, silver, and gold alloys is in the order gold $>$ silver $>$ copper.

A review of the data shows that considerations of size-factor and electron concentration are not by themselves sufficient to explain the facts, but that an additional factor is present to an increasing extent, as the solvent and solute metals differ in their electrochemical properties. In their alloys with electropositive metals (such as magnesium or zinc), copper, silver, and gold are the electronegative members, and the electrochemical factors are in the order gold $>$ silver $>$ copper. In alloys with the electronegative elements (such as arsenic), copper, silver, and gold are electropositive, and the electrochemical factors are in the reverse order, copper $>$ silver $>$ gold. This reversal of the relative electrochemical nature of the solvent and solute takes place at about Group IV.

The tendency to form the $\beta^{\prime}$ structures with longrange order is favoured by an increasing electrochemical factor, and, when this is sufficiently pronounced, the $\beta^{\prime}$ liquids and solidus curves rise to a maximum, as in the system gold-magnesium. A consideration of the effect of the development of longrange order on the form of the equilibrium diagram leads to an explanation of the form of the copperberyllium diagram. An examination of the phase boundaries of the equilibrium diagrams shows that, in many cases where the percentage of the solute is high, the diagrams begin to acquire characteristics that would be expected in ordered structures, even though X-ray investigations show that long-range order does not exist. It is suggested that a shortrange order may be present, and it is shown that this conception accounts for the shapes of parts of the equilibrium diagrams, and for the limiting compositions to which some of the phase boundaries approach.

\section{FORTHCOMING EVENTS}

Tuesday, October 22

Irluminating Engineering Societry (at the E.L.M.A. Lighting Service Bureau, 2 Savoy Hill, London, W.C.2), at 2.30 p.m.-Mr. H. C. Weston : "Industrial I Lighting and the Black-out."

\section{Wednesday, October 23}

North-East Coast Institution of Engineers and ShIPBuILDers (Student Section) (at Bolbec Hall, Newcastle-upon-Tyne), at 6.45 p.m.-Mr. George Wright, jr.: "Relative Merits of Marine Fuels" (Chairman's address).

\section{Thursday, October 24}

Institution of Electrical Engineers (at Savoy Place, Victoria Embankment, Isondon, W.C.2), at 2.30 p.m. -Mr. J. R. Beard: Presidential address.

\section{REPORTS AND OTHER PUBLICATIONS}

(not included in the monthly Books Supplement)

\section{Great Britain and Ireland}

Department of Scientific and Industrial Research. The Investigation of Atmospheric Pollution: Report on Observations in the Year ended 31st March 1939. (Twenty-fifth Report.) Pp. vi $+132+6$ plates.
(London: H.M. Stationery Office.) 28 . 6d. net.

British Electrical and Allied Industries Research Association. Technical Report, Reference $L / T$ 114: The Electric Strength of Solid Dielectrics in relation to the Theory of Electronic Breakdown. Pp. $18+9$ plates. (London: British Electrical and Allied Industries
Research Association.) 38.

\section{Other Countries}

Field Museum of Natural History. Botany Leaflet 25: The Story of Food Plants. By B. E. Dahlgren. Pp. iv +33. (Chicago: Field Museum of Natural History.) 25 cents. [710

Proceedings of the American Academy of Arts and Sciences. Vol. 73 , No. 15: A Symposium on Social Progress. What is Social Progress? by L. J. Henderson; A Paper on Social Progress, by Crane (Boston: American Academy of Arts and Sciences.) 50 cents. [710 Smithsonian Miscellaneous Collections. Vol. 99, No. 6: The Time Course of Photosynthesis and Fluorescence observed Simultaneously. By E. D. McAlister and Jack Myers. (Publication 3591.)
(Was. ii +37.
$[710$

U.S. Department of Agriculture. Technical Bulletin No. 732 : Arsenic Distribution in Soils and its Presence in Certain Plants. By Kenneth 'T. Williams and Richard R. Whetstone. Pp. 20. (Washington, D.C.: Government Printing Office.) 5 cents.

Smithsonian Institution : United States National Museum. Bulletin 100, Vol. 14, Part 1: Contributions to the Biology of the Philippine Archipelago and Adjacent Regions-Report on the Echinoidea colArchipelago and Adjacent Regions-Report on the Echinoidea colExpedition 1907-1910, Part 2: The Echinothuridæ, Salenidææ, Arbaciidæ, Aspipodiadematidæ, Micropygidæ, Diadematidæ, Pedinidæ, Temnopleuridæ, Toxopneustidæ and Echinometridæ, By Theodor Mortensen. Pp. iv +52 . (Washington, D.C.: Government Printing Office.) 10 cents.

Indian Forest Records (New Series). Silviculture, Vol. 4, No. 1 : Canadian Aerial Forestry for Burma. By J. D. Braithwaite. Pp. ix $+96+18$ plates. (Delhi : Manager of Publications.) 3.12 rupees.
[710

United States National Museum. Bulletin 176: Life Histories of North American Cuckoos, Goatsuckers, Hummingbirds and their Allies; Orders Psittaciformes, Cuculiformes, Trogoniformes, Coraciiformes, Caprimulgiformes and Micropodiformes. By Arthur Cleveland Bent. Pp. viii $+506+73$ plates. (Washington, D.C. : Government Printing Office.) 75 cents.

Canada: Department of Mines and Resources, Mines and Geology Branch: Department of Mines an 40-1: Preliminary ap Geology Branch : Geological Survey. Paper 40-1 : Preliminary Map, Jumpingpound, Alberta. By G. S. Hume. 1 map. 10 cents. Paper 40-6 : Preliminary Map, Bragg Creek, Alberta. By G. S. Hume and H. H. Beach. 1 map. 10 cents. Paper 40-8: The Structure and Oil Prospects of the Foothills of Alberta between Highwood and Bow Rivers. By G. S. Hume. Pp. iii $+22+1$ map. 10 cents. Paper 40-10: Stony Rapids and Porcupine River Areas, Saskatchewan. By G. M. Furnival. Pp. $1 i+10+2$ maps. 10 cents. Paper 40-11: The Lloydminster Gas and Oil Area, Alberta and Saskatchewan. By G. S. Hume and C. O. Hage. Pp. ili +12 . 10 cents. Paper 40-12: Zeballos Mining District and Vicinity, British Columbia. By M. F. Bancroft. Pp. iii +39 . 10 cents. Paper 40-14: Quyta Lake and Parts of Fishing Lake and Prosperous Lake Areas, Northwest Territories.) By A. W. Jolliffe.
Pp. iii +9. 10 cents. (Ottawa : King's Printer.) 